\title{
USING SATELLITE DATA FOR ENVIRONMENTAL IMPACT ANALYSIS IN ECONOMIC GROWTH: THE CASE OF MONGOLIA
}

\author{
A.Tungalag ${ }^{\mathrm{a}, \mathrm{b},{ }^{*}}$, R.Tsolmon ${ }^{\mathrm{a}}$, L.Ochirkhuyag $^{\mathrm{b}}$, J.Oyunjargal $^{\mathrm{c}}$ \\ ${ }^{a}$ NUM-ITC-UNESCO Space Science/Remote Sensing Laboratory, National University of Mongolia, \\ Ulaanbaatar - amar tungalag@num.edu.mn, tzr112@psu.edu \\ ${ }^{\mathrm{b}}$ Mongolian Geospatial Association-mongeoinfo@gmail.com \\ ${ }^{\mathrm{c}}$ University of Torino - oyuhaa1@gmail.com
}

Commission VIII, WG VIII/8

\begin{abstract}
KEY WORDS: Satellite Data, Environmental Impact Analysis, Economic growth, The Green Solow model, The Ramsey-
\end{abstract} Cass- Koopmans model

\begin{abstract}
The Mongolian economy is based on the primary and secondary economic sectors of agriculture and industry. In addition, minerals and mining become a key sector of its economy. The main mining resources are gold, copper, coal, fluorspar and steel. However, the environment and green economy is one of the big problems among most of the countries and especially for countries like Mongolia where the mining is major part of economy; it is a number one problem. The research of the work tested how environmental elements effect to current Mongolian economic growth, which is growing economy because of mining sector.

The study of economic growth but the starting point for any study of economic growth is the neoclassical growth model emphasizing the role of capital accumulation. The growth is analysed either in terms of models with exogenous saving rates (the Solow-Swan model), or models where consumption and hence savings are determined by optimizing individuals. These are the so-called optimal growth or Ramsey-Cass-Koopmans. The study extends the Solow model and the Ramsey-CassKoopmans model, including environmental elements which are satellite data determine to degraded land and vegetation value from 1995 to 2013. In contrast, we can see the degraded land area increases from 1995 (4856m2) to 2013 (10478 m2) and vegetation value decrease at same time.

A description of the methodology of the study conducted follows together with the data collected and econometric estimations and calibration with environmental elements.
\end{abstract}

\section{INTRODUCTION}

Rapid growth of world population affects for increasing the carrying capacity of the earth, thus total demand and consumption increasing the production, the usage of increasing demand, increase environmental pollution and emissions. For this reason earth protective ozone becomes thinner and climate change creates dangerous hazards year by year.

These changes affect existence of plants, animals and human and misbalance of nature leads to drying up of river which affect negatively on social life and creates negative impact on the health of population and various kind of diseases that are the mean causes of incident and the lost productivity of population.

Mongolia has traditionally nomadic lifestyle. Before 1990 Mongolia has had heavily dependent on Soviet Union, after its collapse the country has transformed to democratic society. Since democratic movement, the economy growth of the country has been increasing enormously particularly, in last few years the mining industry has been developing rapidly which strongly influence the state's economy. Mongolia can be classified among the resource-rich developing countries as a result of minerals and mining which become a key sector of its economy representing $17 \%$ of the gross domestic product, $65 \%$ of industrial output and $89.2 \%$ of export earnings ${ }^{1}$.

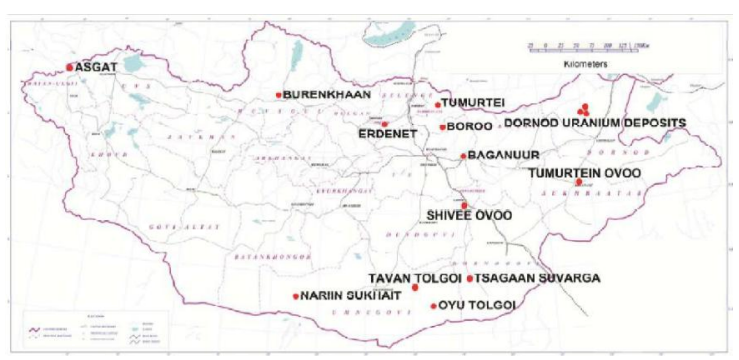

Figure 1. Mongolian Strategic Deposit

Source: PwC, 2015

Fifteen strategically important deposits which adopted by the Parliament of Mongolian in $2007^{2}$, former Minister of Finance Mr S. Bayartsogt announced that "he believes those 15 strategically important mineral deposits could lead to development of country more sustainably", (figure 1). Mining has developed unevenly throughout the world. By 2004 the mining exports of 78 countries accounted for 2.6 percent of the world's annual GDP ${ }^{4}$ but 
mining is widely known to have major negative impacts on the environment, as is the case for most natural resources.

High economic growth in the short term to create a global compliance biases eventually brought environmental degradation, human and animal life and health of generations adversely affected. Through the loss of natural products and services to leave knowing that the world reached the 21 st century without undermining the main development trends in environmental quality and economic growth. Important issue is defined as its time to create economic growth in the environmental impact study.

The objective of this study is to analyze how environmental elements effect to the Mongolian economic growth by using the economic growth models which are the Green Solow. Goals are defined as follows to study of theoretical models, and demonstrate the impact on the environment and analyze the economic growth models with environmental elements, to find the parameters by using econometric estimations and to do calibration, environmental impact analysis in economic growth of Mongolia using the economics' program.

The study uses statistical data and analyses to access the rise in difficulties for mining industry with less environment impact of Mongolia and evaluate the current social and economic situations. We used statistical data and analyses from MODIS satellite data enhanced vegetation value and determining degraded land is to analyze negative impact of mining even it's a one of the important part of economic growth of Mongolia.

Study hypotheses explore the relationship between economic growth and environmental impact by using models of economic growth.

Hypothesis 1: More mining companies start to emerge in Mongolian market, more land is used and degradation of land is increasing.

Hypothesis 2: Not enough rehabilitation is done by the mining companies after the work out.

Hypothesis 3: Degradation of land does not provide plentiful plantation which directly affects the nomadic people who depend on nomadic cattle breeding.

\section{MAIN BODY}

\subsection{Literature review}

There are many theories to analyze the economic growth but we have chosen some of them which concern economic growth and environment elements together and how the researchers provide a summary of their research is also explained. Solow [1] and Swan [2] conducted this model showing how economic growth can be raisin by economic policy by inducing people to save more. But the model also predicts that this kind of increase in growth is not able to last indefinitely. Moreover, context government policy can affect the levels of the key variables but not growth rates which are exogenously determined. In this stage, growth is analyzed either in terms of models with exogenous saving rates (the SolowSwan model), or models where consumption and hence savings are determined by optimizing individuals. These are the so-called optimal growth or Ramsey-CassKoopmans models (Ramsey [8], Cass [9], Koopmans[10]).

\subsection{EMIPRICAL ANALYSIS}

\subsubsection{The current economic situation}

In spite of a rapid increase in the tertiary sector over the last decade, the Mongolian economy is still based on the primary and secondary economic sectors of agriculture and industry. In addition minerals and mining become a key sector of its economy. Full and semi-nomadic herding and mining accounted for 38 percent of GDP in 2010 , of which mining and quarrying comprised 22 percent (Mongolian National Statistical Office, 2011). As Mongolia has two giant economic neighbors, the majority of its exports ( 84 percent) go to China, while 31 percent and 33 percent of total imports come from China and Russia respectively (Mongolian National Statistical Office, 2011). The main exports are 31 cashmere products, meat, and minerals such as copper, molybdenum, gold and fluorite.

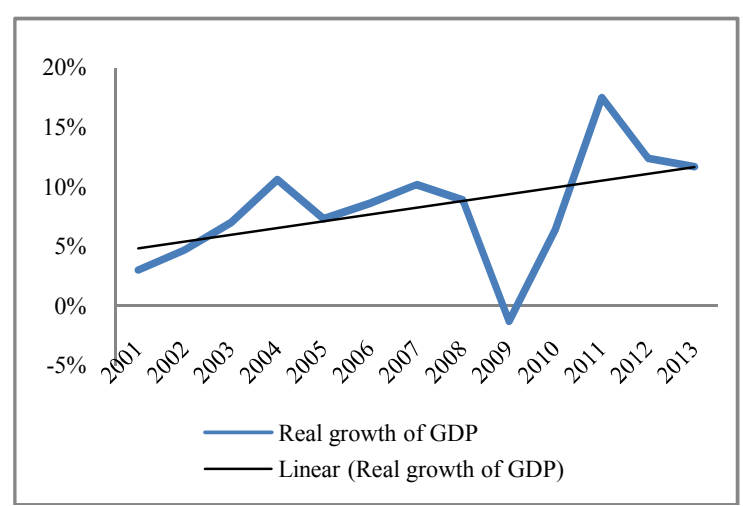

Figure 5. Real growth of GDP by percentage

Source: ${ }^{5}$ Global Finance, Annual Survey: World's Best Banks 2014, May 07, 2014

\subsubsection{The current environment situation}

Mongolia is severely impacted by desertification and climate change. The Gobi desert continues to expand northward, with over $70 \%$ of Mongolia's land degraded through overgrazing, deforestation, and climate change. Degradationis a downward spiral, as degraded lands are less resilient to climate change impacts. Average mean temperature increases are more than $2^{\circ} \mathrm{C}$. Climate-related disasters, including droughts, severe storms, and flashfloods, with high social and economic costs (particularly for herders) have doubled in frequency.

The loss of eco-economic means pollution of environment, loss of natural resources, imbalance of ecology which affect people's health, environment and affects indirectly to economy, society with negative results. Among the adverse effects on environment, the mining is taken as the most harmful one.

Extractive industry and extensive livestock husbandry are increasingly at odds. Mining operations require large amounts of water, and mineral deposits are often located in lands used by herders. This leads to increasing resource competition, with herders often being displaced.

In the territory where mining is developed greatly, it's important to identify natural resource, load capacity and

${ }^{5}$ http://www.gfmag.com 
observation, control and investment of technology should be considered step by step very carefully. The loss of eco-economic environmental compensation should be calculated according to these three categories:

1. Primary rehabilitation- this is the cost to change or bring the nature to its initial condition (before the change on the land).

2. Repair by compensation- the cost to rehabilitee the land and compensate the natural resource from the beginning of pollutant and damage till the date of rehabilitation.

3. The cost to come up with the estimation of the loss. If natural and economic managements are planned accordingly, the rehabilitation of the land would have positive impact on people's health and living condition.

Mongolia started to invest on rehabilitation in order to come up with the global standard. The increasing trend on investment can be seen from figure 13 .

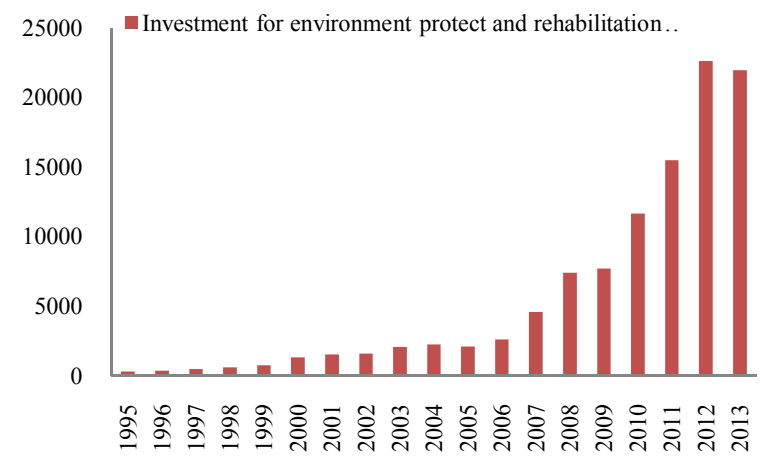

Figure 13. Investment for environment protect and rehabilitation

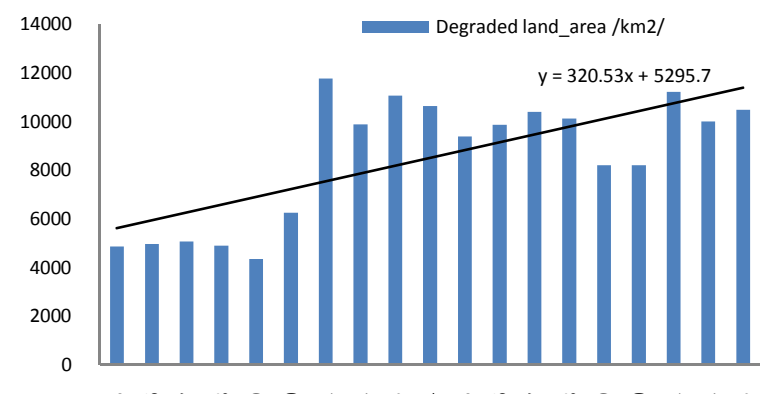

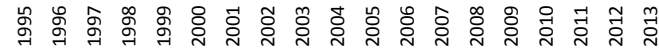

Figure 14. Land degradation $\mathrm{km}^{2}$

Figure 13 and Figure14 shows that when investment for environment protect and rehabilitation increases at the same time the land degradation increases in area of Mongolia. From the environmental Kuznets curve, economic and land degradation have direct relation.
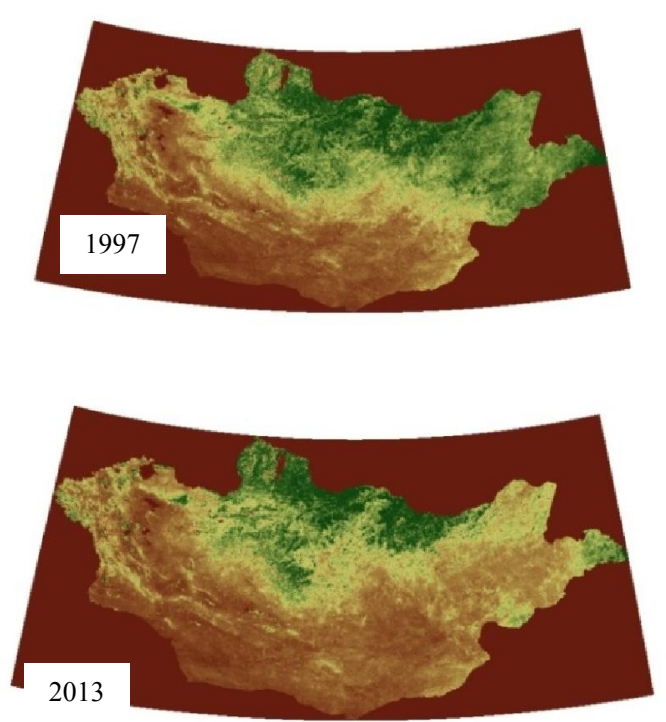

Figure 15. Degradation mapping (MODIS satellite data, EVI 250m)

As from Figure 15, we can see the comparison of degraded land of Mongolia from 1997 to 2013. Therefore, degraded land and vegetation index have indirect relation.

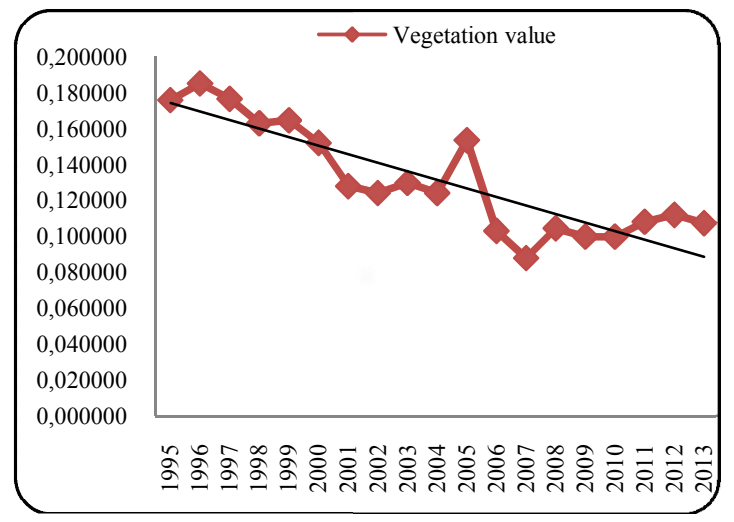

Figure 16. Change detection (Enhanced Vegetation Index)

Mongolian vegetation growth is decreases because of lot of reason which are climate change, desertification etc. but basic reason is degraded land, because of Mongolian mining sector's growth (figure 16).

Finally, currently Mongolian mining sector provides 42 thousand people with the job and it consists of $3 / 4^{\text {th }}$ of total export. However, because of the mining process, the negative impacts on nature are increasing year by year and also damage from mining is increasing at the same time.

\subsection{Estimation Equation}

In this section we present alternative methods to investigate the growth and environment relationship that draws on existing work in macroeconomics. Let to calculate the important parameters of the equations.

\section{Production function estimation}

Production function taken according to the theory. 


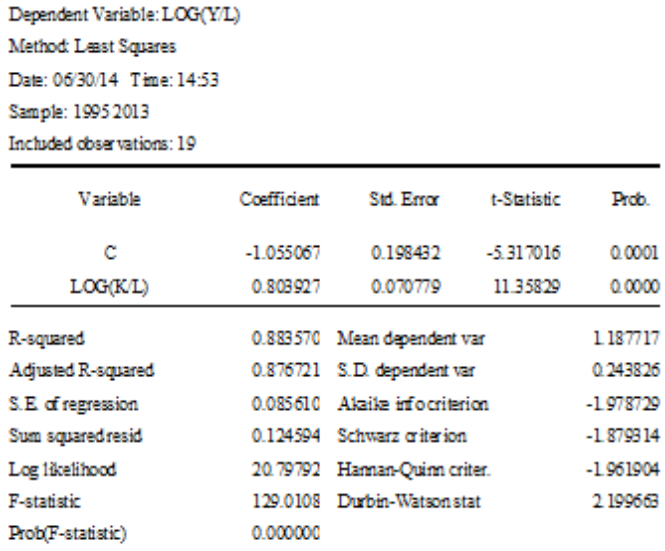

Equation coefficients for the explanatory variables on the value of previous statistical reliability and the ability to interpret $R^{2}=0.88$ which means good, from $d=2.2$ the basic assumption is rejected to be without autocorrelation.F-statistic rejects that all the parameters of regress is equal to zero.Verify compliance with other requirements for the estimation of LM test regression $\operatorname{in} \operatorname{Prob}(F(2,15))=0.68$ being the balance between random variables, independent, heteroskedasticity

test $\operatorname{Prob}(F(2,16))=0.41, \quad$ whether homogeneous,Jargue-Bera as a 0.52 probability of normal distribution.

Therefore, the classical production in all conditions are met, the production function as follows

$$
y=k^{0.8} e^{-1.05}=0.34 k^{0.80}
$$

Here, its represented as $\alpha=0.88$.

\section{Capital change estimation}

Changes in capital as defined in the theoretical section is $d K / d t=I-\delta K$ so it represented as

$$
K_{t}=I_{t}+(1-\delta) \cdot K_{t-1}
$$

\begin{tabular}{|c|c|c|c|c|}
\hline \multirow{2}{*}{\multicolumn{5}{|c|}{ Dependent Variable: $\mathrm{K}$}} \\
\hline & & & & \\
\hline \multicolumn{5}{|l|}{ Method: L mast Squares } \\
\hline \multicolumn{5}{|c|}{ Dete: 0630/14 T ime: 12:19 } \\
\hline \multicolumn{5}{|c|}{ Sample (adjusted) 19962013} \\
\hline \multicolumn{5}{|c|}{ Inchuded obser uations: 18 after adjustments } \\
\hline \multicolumn{5}{|c|}{$\mathrm{K}=\mathrm{O}(\mathrm{l}) \mathrm{I}+\mathrm{C}(2)+\mathrm{K}(-1)$} \\
\hline & Coeffident & St. Enror & t-Satistic & Pada \\
\hline$c(1)$ & 1.237 .947 & 1452598 & 0.852230 & 04067 \\
\hline$\phi(2)$ & 0.920006 & 0.087836 & 10.47638 & 00000 \\
\hline R-squered & 0.898460 & Mean dpendent var & & 1656234 \\
\hline Adjutad R-squared & 0.892113 & S.D dependent ver & & 676035 \\
\hline SE af regrasion & 2200512 & Alaile ifocriterion & & 18.35330 \\
\hline Sum squared resid & 78890763 & Schwarz eiterion & & 18.45222 \\
\hline Log tikelihood & -169.1797 & Haman-Quim criter & & 18.36694 \\
\hline F-statiatic & 1415728 & Dorbin-Watson stat & & 3.263849 \\
\hline Padb(F-statistic) & 0.000000 & & & \\
\hline
\end{tabular}

Explanatory power for the evaluation of this equation is $\mathrm{R}^{2}=0.89$ or better, and $\mathrm{d}=3.26$ or without autocorrelation, whether the LM test in
$\operatorname{Prob}(F(2,14))=0.01$ being the residual random variables correlated, heteroskedasticity test-p $\operatorname{Prob}(F(2,15))=0.48$ whether one type, Jargue-Bera 0.45 is a probability of normal distribution as a 0.79 . therefore, its possible to accept the result of the equation and $\delta=0.08$.

\section{Estimation of increase of number of employees}

Since we can represent the increase of the number of employees as $\dot{L} / L=n$

$$
\ln (L)=L_{0}+n t,
$$

\begin{tabular}{|c|c|c|c|c|}
\hline \multicolumn{5}{|c|}{$\begin{array}{l}\text { Dependent Variable: } L O G(\mathrm{~L}) \\
\text { Method: Lmst Squares } \\
\text { Date: } 0630 / 14 \text { Time: } 12: 35 \\
\text { Sample: } 19952013 \\
\text { Inchuded doss vations: } 19\end{array}$} \\
\hline Variable & Coefficient & StC. Erro & t-Statistic & Prob. \\
\hline c & 6.621476 & 0.013544 & 488.8708 & 00000 \\
\hline बCIREND & 0.022491 & 0.001286 & 17.49494 & 00000 \\
\hline R-squared & 0.947380 & Mean dependent var & & 6823897 \\
\hline Adjusted R-squared & 0.944285 & S.D dependent var & & 0.130032 \\
\hline S.E of regression & 0.030693 & Akaike iffocriterion & & -4.030276 \\
\hline Sum squaredresid & 0.016015 & Schwarz $\propto$ iter ion & & -3.930861 \\
\hline Log 1ikelihood & 40.28762 & Haman-Quim criter. & & -4.013451 \\
\hline F-statistic & $306.072 \mathrm{~s}$ & Durbin-Watson stat & & 0,680096 \\
\hline Prob(F-statistic) & 0.000000 & & & \\
\hline
\end{tabular}

so the direct estimation was done.

To find annual increase of number of employees, its not necessary to provide with regression function, we just have to find the parameter. Therefore, represented as $n=0.022$.

Average growth rate of pollution estimation

Rehabilitation average growth can be expressed as $\dot{E} / E=g_{E}$

$$
\ln (E)=E_{0}+g_{E} t
$$

so the direct estimation was done.

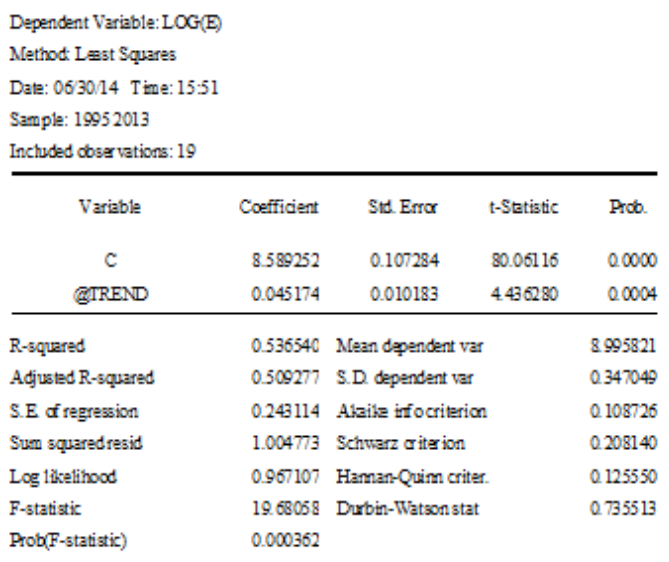

To find the average growth of rehabilitation, its not necessary to provide the classical regression, only need to ensure enough to find the only parameter. So $g_{E}=$ 0.045 that have been expressed. 
The average saving rate

Calculated the average savings per cent of all observations by the average total accumulation and the nominal Gross Domestic Product ratio.

$$
s=\frac{1}{18} \sum_{i=1995}^{2013} \frac{S_{i}}{Y_{i}}=0.29
$$

\section{$\underline{\text { Average rehabilitation }}$}

Average rehabilitation of natural resources conservation and rehabilitation measures the amount of money spent on the nominal gross domestic product compared with the average of all observations were computed.

$$
\theta=\frac{1}{18} \sum_{i=1995}^{2013} \frac{F_{i}^{A}}{F_{i}}=0.0013
$$

\section{Pollution estimation}

Theoretical part of the estimation of pollution identified as $\dot{P}=w Y-\mu P$ and transferred as following disrate.

$$
P_{t}=w Y_{t}+(1-\mu) P_{t-1}
$$

Dependent Variable: $P$

Method: Lmst Squares

Date: 063014 Ties: $13: 27$

\begin{tabular}{|c|c|c|c|c|}
\hline Variable & Coefficient & Sd Error & t-Satistic & Prob. \\
\hline$P(-1)$ & 0.836093 & 0.139006 & 5258264 & 0,0001 \\
\hline$Y$ & 0.458100 & 0.396993 & 1.153927 & 0.2655 \\
\hline R-squared & 0,508462 & \multicolumn{2}{|l|}{ Mean dependent var } & 8703.467 \\
\hline Adjusted R-squared & 0.477741 & \multicolumn{2}{|l|}{ S.D dependent var } & 2485.434 \\
\hline SE ciregresion & 1796160 & \multicolumn{2}{|l|}{ Alaite iffocriterion } & 1792013 \\
\hline Sun squaredresid & 51619073 & \multicolumn{2}{|l|}{ Schwerz attrion } & 18.02806 \\
\hline Log thelihood & -159.362 & \multicolumn{2}{|l|}{ Haman-Quim criter- } & 1794277 \\
\hline Drroin-Watsonstat & 2066916 & & & \\
\hline
\end{tabular}

Semple (adjuated): 19962013

Inchded obserations: 18 after adjustments

$$
P_{t}=0.46 Y_{t}+0.83 P_{t-1}
$$

Explanatory power for the evaluation of this equation, $\mathrm{R}^{2}=0.51$, or poorly, so termed as without autocorrelation as $\mathrm{d}=2.07$, whether the $\mathrm{LM}$ test in $\operatorname{Prob}(F(2,14))=0.85$ being the balance between random variables, independent, heteroskedasticity testProb $(\mathrm{F}(2,15)),=0.81$ whether one type, Jargue-Bera that he probability of 0.00 is not normal expansion.

Moreover, hope for rehabilitation coefficient statistics is poor. Therefore, the equation is not fully reliable estimation. Our goal is to find coefficients so $\mathrm{w}=0.46, \mu$ $=0.16$ is determined.

\subsection{Calibration}

Theoretical models' parameters summarized and shown in the following table.

Table4. Theoretical models' parameters

\begin{tabular}{|c|c|c|c|}
\hline \multicolumn{2}{|c|}{$\begin{array}{c}\text { The Green Solow } \\
\text { model }\end{array}$} & \multicolumn{2}{|c|}{$\begin{array}{c}\text { The Ramsey-Cass-Koopmans model with } \\
\text { environment }\end{array}$} \\
\hline$\alpha=$ & 0.88 & $\alpha=$ & 0.88 \\
\hline$g=$ & 0.025 & $g=$ & 0.025 \\
\hline$\delta=$ & 0.08 & $\delta=$ & 0.08 \\
\hline$n=$ & 0.022 & $n=$ & 0.022 \\
\hline$g_{E}=$ & 0.045 & $w=$ & 0.46 \\
\hline$s=$ & 0.29 & $\mu=$ & 0.16 \\
\hline$\theta=$ & 0.0013 & $k_{0}=$ & 26 \\
\hline$k_{0}=$ & 26 & $p_{0}=$ & 9.2 \\
\hline$e_{0}=$ & 19 & $y_{0}=$ & 5.4 \\
\hline$y_{0}=$ & 5.4 & & \\
\hline
\end{tabular}

To define Solow equilibrium level of design

$$
\dot{k}=s(1-\theta) k^{\alpha}-(\delta+n+g) k
$$

the balance level of capital зэвсэглэмж

$$
\begin{aligned}
k^{*}=\left(\frac{s(1-\theta)}{\delta+n+g}\right)^{\frac{1}{1-\alpha}} & =\left(\frac{0.29(1-0.0013)}{0.08+0.022+0.025}\right)^{\frac{1}{1-0.8}} \\
& =61.7
\end{aligned}
$$

found like this.Now, let's calculate the estimated time of the pollution capital per capita.

The change in per capita emissions

$$
\frac{\dot{e}}{e}=g_{E}-(g+n)+\alpha\left(s(1-\theta) k^{\alpha-1}-(\delta+n+g)\right)
$$

would be like this and determines the level of the pollution of current capital $\mathrm{z}$ equilibrium by zero balance

$$
\begin{aligned}
& k_{e}^{*}=\left(\frac{\alpha s(1-\theta)}{\delta+2(n+g)-g_{E}}\right)^{\frac{1}{1-\alpha}} \\
& =\left(\frac{0.8 \cdot 0.29 \cdot(1-0.0013)}{0.08+2(0.022+0.025)-0.045}\right)^{\frac{1}{1-0.8}}=18.7
\end{aligned}
$$

Calculating the per capita revenues

$$
\begin{aligned}
& y^{*}=0.34 k^{0.8}=0.34 \cdot 61.7^{0.8}=9.2 \\
& y_{e}^{*}=0.34 k^{0.8}=0.34 \cdot 18.7^{0.8}=3.5
\end{aligned}
$$

Here pollution impactsof the capital per capita equilibrium level of 3.3 times the per capita income was reduced by 2.6 times. In other words, the amount of contamination by Solow model is consistent with the value determined by theory which has negative effect on the economy.

Now let's consider the Ramsey model.

$$
\frac{\dot{c}}{c}=\frac{1}{\rho}\left[f^{\prime}(k)\left(1+\frac{\lambda w}{q}\right)-(\varepsilon+g+n+\delta)-\gamma \frac{\dot{p}}{p}\right]
$$


From production function $=k^{\alpha}$, the change of $k$

$$
f^{\prime}(k)=\alpha k^{\alpha-1} \dot{k}
$$

will be like this. Therefore, changes in per capita consumption

$$
\frac{\dot{c}}{c}=\frac{1}{\rho}\left[\alpha k^{\alpha-1} \dot{k}\left(1+\frac{\lambda}{q} w\right)-(g+n+\delta)-\gamma \frac{\dot{p}}{p}\right]
$$

would be this. Now from equilibrium levels that is $\dot{k}=\dot{p}=0$, the consumption change

$$
\begin{array}{r}
\frac{\dot{c}}{c}=-\frac{g+n+\delta}{\rho} \\
\text { Or } c_{t}=c_{0} \exp \left(-\frac{g+n+\delta}{\rho} t\right)
\end{array}
$$

when $\mathrm{t} \rightarrow \infty$, consumption is zero. Therefore,

to find $k$

$$
\begin{aligned}
& \dot{k}=f(k)-(g+n+\delta) k \\
& \dot{p}=w y-(\mu+g+n) p \\
& k^{*}=\left(\frac{1}{\delta+n+g}\right)^{\frac{1}{1-\alpha}}=30267
\end{aligned}
$$

will be like this and replaced with pollution levels

$$
p^{*}=w\left(\frac{1}{\delta+n+g}\right)^{\frac{\alpha}{1-\alpha}} \frac{1}{\mu+g+n}=8542
$$

Here the model Ramseyis not convenient with reality.

\section{CONCLUSION}

The main mining resources are gold, copper, coal, fluorspar and steel. Mongolia can be classified among the resource-rich developing countries as a result of minerals and mining which become a key sector of its economy representing $17 \%$ of the gross domestic product, $65 \%$ of industrial output and $89.2 \%$ of export earnings and this sector provides 42 thousand people with the job.

However, the environment and green economy is one of the big problems among most of the countries and especially for countries like Mongolia where the mining is major part of economy, it is a number one problem. Because of the mining process, the negative impacts on nature are increasing year by year and also damage from mining is increasing at the same time. As shown figure 14 , we can see the degraded land area increases from $1995\left(4856 \mathrm{~m}^{2}\right)$ to $2013\left(10478 \mathrm{~m}^{2)}\right.$ and vegetation value decreases (figure 16) at same time.

In this paper, the Green Solow and the Ramsey-CassKoopmans models are used and from the results we can see that the Green Solow model is more convenient with Mongolian condition. Even we tried to come up with the united result from two models, we reached solution from only one model.

It's estimated in the study that the environmental elements have negative impact on Mongolian economy. If we neglect impact of environment, income per capita would decrease by 2.6 times and capital per capita would decrease by 3.3 times respectively.

\section{REFERENCES}

[1] R.M.Solow, "A contribution to the theory of economic growth", Quarterly Journal of Economics, 70, 1956, pp.65-94
[2] T.W.Swan, Economic growth and capital accumulation, Economic Record, 32, 1956, pp.334-361

[3] R.F.Harrod, An essay on the Principle of Population, Cambridge University Press, Cambridge, 1992

[4] E.D.Domar, Capital expansion, rate of growth and employment, Econometrica, 12, 1946, pp.137-147

[5] R.J.Barro and X.Sala-i-Martin, Economic Growth, MCGraw-Hill, New York, 1995

[6] T.R.Malthus, An Essay on the Principle of Population, Cambridge University Press, Cam-bridge, 1992.

[7] P.F.Verhulst, Noticesur la loique la population pursuit dans son accroissement, Correspon-dance Mathematique' et Physique,10,1838, pp.113-121

[8] Ramsey, Frank (1928): “A Mathematical Theory of Saving," Economic Journal, 38(152), 543-559.

[9] Cass, David (1965):"Optimum growth in an aggregative model of capital accumulation," Review of Economic Studies, 32, 233-240.

[10] Koopmans, Tjalling C. (1965): "On the concept of optimal economic growth," in (Study Week on the) Econometric Approach to Development Planning, chap. 4, pp. 225-87. North-Holland Publishing Co., Amsterdam.

[11] Porter, M.E., 1991. America's green strategy. Scientific America 264, 168

[12] Van der Linde., Porter, M.E, C., 1995. Toward a new conception of the environment competitiveness relationship. Journal of Economic Perspectives 9 (4), 97118.

[13] Copeland, B.R. and M.S.Taylor (1994), "NorthSouth Trade and the Global Environment", Quarterly Journal of Economics 109: 755-87

[14] William A. Brock, The green solow model, National bureau of economic research, 1050 Massachusetts Avenue, Cambridge, MA 02138, June 2004

[15] M. Scott Taylor, The green solow model, National bureau of economic research, 1050 Massachusetts Avenue, Cambridge, MA 02138, June 2004

[16] David Romer, Advanced Macroeconomics, 1996

[17] Pranab Bardham and Christopher Udry, "Development Microeconomic", Oxford New York, 1999

[18] Massimiliano ferrara, Luca guerrini, More on the Green Solow Model with Logistic Population Change, 2009

[19] Tumurbaatar Enkhtulga, "To analyse the ecological and financial of damage from the environment of minig industry", Ulaanbaatar, 2010

[20] Pranab Bardham and Christopher Udry, "Development Microeconomic", Oxford New York, 1999

[21] Joshua D. Angrist, Jörn-Steven Pischke Mostly Harmless Econometrics: An Empiricist.s Companion, 2008 
The International Archives of the Photogrammetry, Remote Sensing and Spatial Information Sciences, Volume XLI-B8, 2016 XXIII ISPRS Congress, 12-19 July 2016, Prague, Czech Republic

5. Appendix- Used statistical data

\begin{tabular}{|c|c|c|c|c|c|c|}
\hline Year & $\begin{array}{l}\text { Real GDP } \\
\text { (trillion tug) }\end{array}$ & $\begin{array}{l}\text { Total savings } \\
\text { (trillion tug) }\end{array}$ & $\begin{array}{l}\text { Nominal GDP } \\
\text { (trillion tug) }\end{array}$ & $\begin{array}{c}\text { Employees } \\
\text { (thous.persons) }\end{array}$ & $\begin{array}{c}\text { Population } \\
\text { (thous. } \\
\text { persons) }\end{array}$ & $\begin{array}{c}\text { Investments, by divisions, } \\
\text { at } 2005 \text { prices }\end{array}$ \\
\hline 1995 & 1941.5 & 76.5 & 651.5 & 767.6 & 2243.0 & 300.9 \\
\hline 1996 & 1984.9 & 86.7 & 738.0 & 769.6 & 2276.0 & 402.9 \\
\hline 1997 & 2062.2 & 120.3 & 932.9 & 765.1 & 2307.5 & 412.4 \\
\hline 1998 & 2131.1 & 110.8 & 945.5 & 792.6 & 2340.1 & 505.1 \\
\hline 1999 & 2196.5 & 132.9 & 1080.5 & 813.6 & 2373.5 & 564.5 \\
\hline 2000 & 2221.7 & 157.9 & 1224.1 & 809.0 & 2407.5 & 568.8 \\
\hline 2001 & 2287.3 & 221.9 & 1391.9 & 832.3 & 2442.5 & 569.5 \\
\hline 2002 & 2395.5 & 349.5 & 1550.6 & 870.8 & 2475.4 & 594.1 \\
\hline 2003 & 2563.3 & 571.8 & 1829.1 & 926.5 & 2504.0 & 835.7 \\
\hline 2004 & 2835.7 & 703.5 & 2361.2 & 950.5 & 2533.0 & 856.4 \\
\hline 2005 & 3041.4 & 987.8 & 3041.4 & 968.3 & 2562.4 & 900.3 \\
\hline 2006 & 3301.6 & 1351.4 & 4027.6 & 1009.9 & 2594.8 & 878.2 \\
\hline 2007 & 3640.0 & 2117.9 & 4956.6 & 1024.1 & 2635.2 & 1288.6 \\
\hline 2008 & 3964.0 & 1941.3 & 6555.6 & 1041.7 & 2683.5 & 1597.5 \\
\hline 2009 & 3913.7 & 2595.0 & 6590.6 & 1006.3 & 2716.3 & 1135.0 \\
\hline 2010 & 4162.8 & 4291.8 & 8414.5 & 1033.7 & 2761.0 & 1348.7 \\
\hline 2011 & 4891.8 & 5894.8 & 11087.7 & 1037.7 & 2811.6 & 2397.0 \\
\hline 2012 & 5498.5 & 7012.4 & 14012.9 & 1056.4 & 2867.7 & 2694.3 \\
\hline 2013 & 6144.2 & 8868.8 & 17550.2 & 1135.3 & 2931.3 & 2764.9 \\
\hline Year & Net capital account & $\begin{array}{r}\text { Investm } \\
\text { and }\end{array}$ & $\begin{array}{l}\text { ironment protect } \\
\text { ion (mil.tug) }\end{array}$ & Vegetation condition & Vegetation index & Degredad land \\
\hline 1995 & 9147.1 & & & 0.30 & 0.1759 & 4856.0 \\
\hline 1996 & 10886.8 & & & 0.20 & 0.1852 & 4960.0 \\
\hline 1997 & 10803.2 & & & 0.41 & 0.1766 & 5060.0 \\
\hline 1998 & 10319.6 & & & 0.51 & 0.1629 & 4903.0 \\
\hline 1999 & 8791.6 & & & 0.41 & 0.1646 & 4348.0 \\
\hline 2000 & 11963.7 & & & 0.35 & 0.1521 & 6239.0 \\
\hline 2001 & 10500.5 & & & 0.42 & 0.1279 & 11753.1 \\
\hline 2002 & 11967.5 & & & 0.53 & 0.1241 & 9879.1 \\
\hline 2003 & 12163.5 & & & 0.21 & 0.1297 & 11060.9 \\
\hline 2004 & 15335.8 & & & 0.11 & 0.1242 & 10629.2 \\
\hline 2005 & 12346.7 & & & 0.21 & 0.1535 & 9379.0 \\
\hline 2006 & 16781.4 & & & 0.11 & 0.1030 & 9862.9 \\
\hline 2007 & 15954.7 & & & 0.21 & 0.0879 & 10390.4 \\
\hline 2008 & 21787.7 & & & 0.21 & 0.1045 & 10111.0 \\
\hline 2009 & 21395.2 & & & 0.42 & 0.0998 & 8195.5 \\
\hline 2010 & 22757.0 & & & 0.31 & 0.0998 & 8195.5 \\
\hline 2011 & 26683.2 & & & 0.51 & 0.1081 & 11216.1 \\
\hline \multirow[t]{2}{*}{2012} & 28097.4 & & & 0.41 & 0.1119 & 10001.4 \\
\hline & 29586.6 & & & 0.34 & 0.1073 & 10478.3 \\
\hline
\end{tabular}

